\author{
Biljana Božinovski \\ Ljubljanska borza, d. d., Ljubljana
}

\title{
The Language of the Stock Exchange - A Contrastive Analysis of the Lexis
}

V članku je podana analiza jezika borze s stališča slovensko-angleške protistave. Izrazje (samostalniške zveze) obeh jezikov smo protistavili tako v strukturnem kot v semantičnem smislu, pri čemer se je razkrilo več protistavnih značilnosti, med drugim različni načini ubeseditve istega pojma, terminološke praznine in lažni prijatelji, slovensko borzno terminologijo pa zaznamujejo tudi angleške tujke.

The article analyzes the language of the stock exchange from a Slovene-English contrastive viewpoint. The specialized lexis of the two languages was juxtaposed as to the structural and semantic differences of their respective terms and expressions (nominal phrases), revealing such contrastive phenomena as different conceptualizations, terminological gaps and false friends, while the Slovene stock exchange terminology is also characterized by English foreignisms.

\section{Introduction}

James characterizes contrastive analysis (CA) as a hybrid linguistic discipline (1989: 4), since it is neither particularist nor generalist and is interested both in the immanent genius of a language and in the ways in which one language compares to other languages. CA does not strive to classify languages and is interested both in the differences and similarities between them.

Having had strictly pedagogical implications at first, the theoretical foundations of CA were initially laid down by Robert Lado in his Linguistics Across Cultures (1957). Lado supported the conviction that if learners of a foreign language (L2) were made aware of the ways in which their mother tongue (L1) and L2 differed, this would facilitate foreign language learning. He went even further by claiming that the elements of L2 that are similar to the learners' L1 will prove simple to learn, with those that are different being difficult. Lado was the first to suggest a systematic set of technical procedures for the contrastive study of languages; this included descriptions of languages and their comparisons as well as predictions of L2 learning difficulties.

In its most ambitious phrasing, the Contrastive Analysis Hypothesis claimed to be able to predict all learners' errors committed in using an L2. However, empirical studies conducted during the 1970s could not sustain this claim, making it clear that CA could only predict certain problematic areas for learners and some of the errors they are bound to make in their versions of L2 (James 1989: 145; my italics).

All comparisons work on the basis of the assumption that the entities to be compared have certain things in common, and that any differences between them can be laid 
against this common background. A CA thus always involves a common linguistic platform of reference, against which contrastive deviations are stated. This common platform is termed tertium comparationis (TC). Depending on the adopted TC, the same aspects of language may turn out be similar or different (Krzeszowski 1990: 16). In syntactic and lexical contrastive studies, the TC is often taken to be formal or semantic correspondence (ibid.), chiefly in combination.

Contrastive linguistics is not a unified field of study. The focus may be on general or on language specific features. The study may be theoretical (theoretical CA), without any immediate application, or it may be applied (applied CA), i.e. carried out for a specific purpose (Fisiak 1981: 2-3). Further, Gabrovšek (2005: 75-6) points out that contrastive work can be done at the levels of: phonology, graphology, lexicology, grammar, and textology. This is why any contrastive work must necessarily be limited in scope and thus always represent but a fragment of the overall contrastive landscape of a given pair of languages.

Contrastive lexicology is the contrastive study of the vocabularies of two (or more) languages. It concerns itself with the transposition of lexical items from L1 to L2 and vice-versa, facing such difficulties as culture-bound vocabulary, interlingual mismatches, lexical gaps, etc (ibid.: 62-194). Equivalence between lexical items in two languages can be complete (trgovalni dan-trading day), partial (organizirani trg-regulated market), or nil (TUVL; insider). There are two possible scenarios in transposing such problematic lexical units: either the L2 equivalent is completely unknown to us (what, for example, is naročilo z razponom in odstranitvijo neizvršene količine in English), which might lead to considerable confusion or even a communication breakdown, or we are uncertain as to the correct collocate (is SLO organizator trga EN market organizer or market operator?), which may make our L2 unidiomatic, but does not impede successful communication. Depending on the pattern and environment it appears in, a lexical item will typically benefit from additional semantic shading imposed by the surrounding lexical elements (semantic tailoring), and often consequently receive different counterparts in L2. Note the pairs sveženj-bundle, avkcija - auction, majhen - small, but (in a stock exchange context) sveženj-block (trade), prekinitvena avkcija - volatility interruption, mali vlagatelj-retail investor. The collocator and the base, even if lexically predictable in L2, may appear in the opposite order in the two languages (zašcita vlagateljev-investor protection) or be joined by a different preposition (trgovati z obveznicami - trade in bonds). Another collocation-related problem, interlingually, is false friends: (borzna) kotacija $\neq$ (market) quotation. Lexicological CA also deals with divergent polysemy (vzdrževalec likvidnosti-liquidity provider or market maker).

This article focuses on lexical contrastive studies and chooses as its TC the English and Slovene lexis of the language of the stock exchange, juggling between formal and semantic equivalence of the terms and expressions in the two languages. Taking the Slovene-English contrastive viewpoint, we focused on nominal phrases (NPs), which have been examined as to the types of (non-)correspondence, on the structural as well as semantic level. The aim of this article has not been a discussion of terminology as such; terminology is here solely the object of contrastive lexicology, which lies at the core of this paper. 
As to the structural aspect, a divergence had been expected of the following kind:

\begin{tabular}{r|l} 
SLO & EN \\
\hline simple NP & $\begin{array}{l}\text { simple NP } \\
\text { complex NP }\end{array}$ \\
\hline complex NP & $\begin{array}{l}\text { complex NP } \\
\text { simple NP }\end{array}$
\end{tabular}

On the semantic level, an occasional discrepancy had been anticipated between the meaning of a particular NP in isolation and that in a particular context (in different word combinations, most notably collocations), semantic tailoring being a feature of not only LGP (language for general purposes) but also LSP (language for special purposes). We had thus expected NPs to have different translation equivalents in different environments. English being the lingua franca of the financial world, we had also expected to find the English terms to be of a much more specialized nature than their Slovene counterparts.

\section{Materials and methods}

The present CA entailed a lexicological comparison of pairs of (original) Slovene and (translated) English texts used in the regular operations of the Ljubljana Stock Exchange Inc. (LJSE). In juxtaposing texts with the same TC - the common platform for comparison was stock exchange terminology-pairs of lexemes (terms and expressions) relevant to our discussion were singled out and compared as to their structural and semantic properties. Given that we dealt with an LSP, our primary concern was with NPs, which constitute the main part of any LSP. The analysis was based on the thus-compiled database of over 1,000 pairs of headwords, of which only a selection appears in this article.

\section{Analysis}

3.1. $\quad$ SLO: simple NP $\rightarrow \quad$ EN: simple NP

\begin{tabular}{r|r} 
avkcija & auction \\
ČVS & NAV \\
delnica & share \\
delničar & shareholder \\
dividenda & dividend \\
glavnica & principal \\
indeks & index \\
izdaja & issue \\
naložba & investment \\
naročilo & order \\
obveznica & bond \\
posel & trade
\end{tabular}




\section{1. $\quad$ SLO: simple NP $\rightarrow \quad$ EN: simple NP (continued)

\begin{tabular}{r|r} 
promet & turnover \\
sklad & fund \\
sveženj & block \\
trg & market
\end{tabular}

The logical English equivalents for promet, posel and izdaja in general language or in isolation would be, for example, traffic, business and betrayal, with bond, auction and share being translated into Slovene as vez, dražba and delež, but in a stock exchange context the respective equivalents are LSP specific and uncontroversial. Sveženj and trg prove more problematic. The former can either be translated as block (of securities) or as block trade, since it can refer to a particular quantity of securities or to a trade executed in that particular quantity of securities - both sveženj in Slovene. Trg can either be rendered as single-word market or compound order book, depending on the context. In the case of the securities market in general, $\operatorname{trg}$ is equivalent to the EN market, but in combination with the trading platform and orders placed in the trading system, trg will normally be order book (naročila na trgu-orders sitting in the order book).

SLO avkcija and dividenda are LSP terms of an international character, having been adopted from English (which their English counterparts clearly show), while the others are Slovene words. While avkcija, trg, izdaja, and naročilo are polysemous words of widespread use in Slovene LGP and only obtain specialized meanings when used in proper stock exchange contexts, dividenda, sklad, delnica, glavnica, naložba and obveznica are financial terms of an inherently terminological nature. In English, the situation is slightly different; only dividend and investment belong to the financial field, while all other words have a wide range of uses and senses.

In their full versions, $\check{C} V S$ (čista vrednost sredstev) and $N A V$ (net asset value) are structurally divergent but lexically transparent.

\begin{tabular}{|c|c|c|}
\hline SLO: simple NP & \multicolumn{2}{|c|}{ EN: complex NP } \\
\hline borza & stock exchange & {$[\mathrm{N}+\mathrm{N}]$} \\
\hline okapitalizacija & capital increase & {$[\mathrm{N}+\mathrm{N}]$} \\
\hline kupnina & purchase price & {$[\mathrm{N}+\mathrm{N}]$} \\
\hline lot & trading unit & {$[\mathrm{Adj}+\mathrm{N}]$} \\
\hline nezaupnica & vote of no confidence & {$[\mathrm{N}+\mathrm{PP}]$} \\
\hline pooblaščenec & proxy holder & {$[\mathrm{N}+\mathrm{N}]$} \\
\hline pripojitev & merger by acquisition & {$[\mathrm{N}+\mathrm{PP}]$} \\
\hline Statut & Articles of Association & {$[\mathrm{N}+\mathrm{PP}]$} \\
\hline VEP & NAV per unit & {$[\mathrm{N}+\mathrm{PP}]$} \\
\hline
\end{tabular}

Except for dokapitalizacija - capital increase, kupnina - purchase price, pripojitev-merger by acquisition and nezaupnica - vote of no confidence, which share at least some lexical elements, the remaining pairs are lexically completely divergent. 


\begin{tabular}{|c|c|c|}
\hline SLO: simple NP & EN: simple NP & \\
\hline enota premoženja & {$[\mathrm{N}+\mathrm{N}]$} & unit \\
\hline finančne terminske pogodbe & {$[\mathrm{Adj}+\mathrm{NP}]$} & futures \\
\hline indeksna točka & {$[\mathrm{Adj}+\mathrm{N}]$} & point \\
\hline izključitev iz (borznega) trga & {$[\mathrm{N}+\mathrm{PP}]$} & delisting \\
\hline izvedeni finančni inštrument & {$[\mathrm{Adj}+\mathrm{NP}]$} & derivative \\
\hline korak kotacije & {$[\mathrm{N}+\mathrm{N}]$} & tick \\
\hline Ljubljanska borza & {$[\mathrm{Adj}+\mathrm{N}]$} & LJSE \\
\hline naročilo za nakup in prodajo & {$[\mathrm{N}+\mathrm{PP}]$} & quote (n.) \\
\hline številka posla & {$[\mathrm{N}+\mathrm{N}]$} & ticket \\
\hline trgovalna koda & {$[\mathrm{Adj}+\mathrm{N}]$} & ticker \\
\hline vrednostni papir & {$[\mathrm{Adj}+\mathrm{N}]$} & security \\
\hline
\end{tabular}

The lexically completely divergent Ljubljanska borza and LJSE deserve a word of mention. While having an adjectival premodifier (denoting the place) and a simple nominal head (denoting the institution) in Slovene, English lexicalizes the concept differently in several respects. First, Ljubljana in Ljubljana Stock Exchange is a nominal premodifier, as opposed to the adjective ljubljanski. Further, the simple borza has a complex equivalent in English, namely the compound stock exchange, the two terms being lexically miles apart (the word borza itself has nothing in common with stocks or securities or exchanges of any kind). What is more, all this is packaged into an English acronym of the stock exchange name, thus $L J S E$, which is common practice with English names of stock exchanges (New York Stock Exchange-NYSE, London Stock Exchange-LSE, National Association of Securities Dealers Automated Quotations - NASDAQ), while less so in Slovene. The Slovene name of the exchange either appears in its full form or is shortened to borza.

English abbreviations and acronyms are a common feature of stock exchange terminology and have penetrated Slovene in their original forms in large numbers. Examples include ETF (exchange traded fund - indeksni vzajemni sklad), SI (systematic internalizer - sistematični internalizator), MiFID (Markets in Financial Instruments Directive-direktiva o trgu finančnih instrumentov), OTC (over-the-counter, which has no lexicalized equivalent in Slovene), FOK (fill-or-kill-naročilo z razponom in odstranitvijo neizvršene količine). In these cases, there are no equivalent Slovene abbreviations (although descriptive equivalents do exist), since the English ones are recognized and actively used by all Slovene speakers of the LSP in question. Note also the difference between the highly idiomatic fill-or-kill as opposed to the descriptive Slovene expression.

\section{4. $\quad$ SLO: complex NP $\rightarrow \quad$ EN: complex NP}

3.4.1. Structurally and lexically transparent equivalents

avkcijsko trgovanje $\mid$ auction trading borznoposredniška hiša brokerage house 


\subsubsection{Structurally and lexically transparent equivalents (continued)}

elektronsko trgovanje finančni instrument institucionalni vlagatelj javna družba trgovalni dan electronic trading financial instrument institutional investor public company trading day

Note further instances of the so-called international words in both columns, underlining the international character of the terminology: avkcijsko-auction, finančni-financial, instrument - instrument, elektronsko - electronic, institucional$n i$-institutional. Although we do have a native Slovene word for institution, which is ustanova, there is no semantically corresponding Slovene adjective (ustanovni in this case would be a false friend); this is why the Slovene term employs the international premodifier.

\subsubsection{Structurally parallel, lexically unpredictable equivalents}

$$
\begin{array}{r}
\text { borzna kotacija } \\
\text { organizirani trg } \\
\text { mali vlagatelj } \\
\text { prosti trg } \\
\text { enotni tečaj } \\
\text { prva javna prodaja } \\
\text { bikovski trend } \\
\text { imenske delnice } \\
\text { podjetniške obveznice } \\
\text { javne obveznice } \\
\text { vzajemni sklad }
\end{array}
$$

Here we have NPs of the uniform structure Adj $+\mathrm{N}$ on both sides, and what is problematic is the lexical choices - either of premodifiers or of heads. In place of official one would expect a fusion with the words stock exchange (judging from borzen). Kotacija does have a direct translation, namely quotation, but the English term refers to the highest bid or lowest ask price available on a security at any given time and thus the two are false friends. The very specific Slovene term borzna kotacija, which stands for the part of the LJSE regulated market intended for companies complying with strict reporting and disclosure obligations, only has one equivalent in English, namely official market. For organizirani trg, many would expect organized market, which, however, is a mistranslation. Instinctively, and not being familiar with stock exchange terminology, a translator might also be tempted to translate the seemingly unproblematic mali vlagatelj as something like small investor, which would of course result in implications divorced from the stock exchange context.

If looked at in isolation, prost, enoten, prodaja, trend, imenski, kotacija, podjetniški, javen would all get translations different from those in the above right 
column. Here they appear in typical multi-word lexical items from the language of the stock exchange, and demand specific equivalents.

The above pairs are also illustrative of the different conceptualizations in the two languages. Take podjetniške obveznice - they are not *entrepreneurial bonds or * company bonds, but rather private bonds. What is more, although one might expect, in view of the logic of things, the opposite of private to be public bonds, English nevertheless calls them government bonds (while Slovene does see them as public, thus javne obveznice).

\subsubsection{Structurally divergent, lexically parallel equivalents}

3.4.3.a. Opposite order of lexemes or different parts of speech

\begin{tabular}{rl|ll} 
delnica [prostega trga] & $\mathrm{N}+[\mathrm{NP}]$ & [semi-official market] share & {$[\mathrm{NP}]+\mathrm{N}$} \\
družba za upravljanje & $\mathrm{N}+\mathrm{PP}$ & management company & $\mathrm{N}+\mathrm{N}$ \\
[dvotirni] sistem [vodenja & {$[\mathrm{Adj}]+\mathrm{N}+$} & [two-tier management] & {$[\mathrm{NP}+\mathrm{N}]+$} \\
družb] & {$[\mathrm{NP}]$} & system & $\mathrm{N}$ \\
indeks [blue-chip delnic] & $\mathrm{N}+[\mathrm{NP}]$ & blue-chip index & $\mathrm{N}+\mathrm{N}$ \\
indeks [celotnega trga] & $\mathrm{N}+[\mathrm{NP}]$ & [total market] index & {$[\mathrm{NP}]+\mathrm{N}$} \\
indeks obveznic & $\mathrm{N}+\mathrm{N}$ & bond index & $\mathrm{N}+\mathrm{N}$ \\
posel s svežnjem & $\mathrm{N}+\mathrm{PP}$ & block trade & $\mathrm{N}+\mathrm{N}$ \\
struktura prometa & $\mathrm{N}+\mathrm{N}$ & turnover structure & $\mathrm{N}+\mathrm{N}$ \\
vzdrževalec likvidnosti & $\mathrm{N}+\mathrm{N}$ & liquidity provider & $\mathrm{N}+\mathrm{N}$
\end{tabular}

In phrases with indices, Slovene has plural nominal postmodifiers in the genitive case (indeks obveznic), while English will typically lexicalize the same concept though a singular nominal premodifier in the nominative (bond index). The delnice part of the respective Slovene NPs (indeks blue-chip delnic, indeks delnic investicijskih skladov) has a nil realization in English (blue-chip index, investment fund index).

\subsection{3.b. Structurally different premodifiers}

\begin{tabular}{r|l} 
avkcijsko trgovanje & auction trading \\
celotna tržna kapitalizacija & total market capitalization \\
delniška družba & joint-stock company \\
osnovni kapital & share capital \\
presežni certifikat & outperformance certificate \\
tekoči podatki & real-time data \\
tržna kapitalizacija & market capitalization \\
tržno naročilo & market order \\
& price-sensitive information \\
cell-informed investor
\end{tabular}


Slovene uses adjectival premodifiers where English has nominal ones, except in the last two cases, which both share the structure of a nominal head premodified by an adjective and even share the same head, but employ different premodifiers; the Slovene premodifier has the head občutljiv premodified by the adverb cenovno, whereas in English the same information is lexicalized through a compound composed of a noun (price) and an adjective (sensitive).

\subsection{3.c. Structurally different postmodifiers}

delnice investicijskih skladov predčasni odkup delnic stopnja donosa

tržna kapitalizacija obveznic shares of investment funds early redemption of shares rate of return market cap of bonds

The recurrent pattern here is a nominal postmodifier in the genitive case in Slovene as opposed to a postmodifying prepositional phrase (PP) - typically the of-phrase, as shown by all of the above examples - in English. Both groups of postmodifiers have the same function (namely that of expressing genitival relations), irrespective of their having different constructions; Slovene being a synthetic language, its expression of the genitive involves attaching genitival suffixes on postmodifying nouns, with English, an analytic language, having the same content expressed through an independent morpheme (the preposition of).

Postmodifiers may be PPs on both sides, but with different heads:

\begin{tabular}{rl|ll} 
sredstva v upravljanju & $\mathrm{N}+\mathrm{PP}$ & $\begin{array}{l}\text { assets under management } \\
\text { trading in bonds }\end{array}$ & $\mathrm{N}+\mathrm{PP}$ \\
trgovanje z obveznicami & $\mathrm{N}+\mathrm{PP}$ & $\begin{array}{l}\text { sistematični } \\
\text { systematic internalizer in }\end{array}$ & $\mathrm{NP}+\mathrm{PP}+\mathrm{PP}$ \\
shares &
\end{tabular}

\subsubsection{Structurally and lexically divergent equivalents}

3.4.4.a. Explanatory equivalent $\mathrm{EN}$

\begin{tabular}{r|l} 
BTS & $\begin{array}{l}\text { BTS trading system } \\
\text { GBD }\end{array}$ \\
GBD brokerage house \\
market maker TUVL segment
\end{tabular}

The acronym TUVL stands for Trg uradnih vzdrževalcev likvidnosti, BTS for borzni trgovalni sistem and GBD for Gorenjska borznoposredniška hiša, none of which have English counterparts. There are other Slovene acronyms and abbreviations that do not have direct English equivalents and need explanatory phrases when being translated into English, e.g., CTG (celotna globina trga), ATVP (Agencija za trg vrednostnih paprijev), KDD (Centralna klirinško depotna družba), DZU (družba za upravljanje), ID (investicijska družba), PID (pooblaščena investicijska družba), and others. Disregarding the names of institutions, only a few are left, a situation 
somewhat different from that in English, which abounds in abbreviated forms. These, in turn, do typically not require explanatory Slovene phrases to be understood by Slovenes, being used world-wide by the speakers of the LSP in question. Slovene abbreviations, on the other hand, are not self-explanatory or known to English speakers, and therefore do need explanations. Cf. 3.3.

\subsection{4.b. Non-transparent equivalents}

Below are a few groups of recurrent constructions that appear in the two languages as equivalent:

SLO: NP [NP(nomin.)+NP(gen.)] $\mid$ EN: NP [NP+N]

[Kodeks upravljanja] [javnih delniških družb] [Corporate Governance] Code

$$
\begin{aligned}
& \text { SLO: } \mathrm{NP}[\mathrm{N} \text { (nomin.)+N(gen.)] } \mathrm{EN}: \mathrm{NP}[\mathrm{N}+\mathrm{N}] \\
& \text { nihanje cen price volatility } \\
& \text { obrat kapitalizacije turnover rate } \\
& \text { plačilo kuponov coupon payment } \\
& \text { revizija indeksov index review }
\end{aligned}
$$

SLO: NP [N(nomin.)+NP(gen.)] $\quad$ EN: NP [NP+N]

indeks [delnic borznega in prostega trga] [total market] index

Note the contrastively problematic EN index review (similarly index perform-

\begin{tabular}{|c|c|}
\hline $\begin{array}{r}\text { SLO: NP [N(nomin.)+NP(gen.)] } \\
\text { datum [zapadlosti zadnjega kupona] }\end{array}$ & $\begin{array}{l}\mathrm{EN}: \mathrm{NP}[\mathrm{N}+\mathrm{N}] \\
\text { coupon date }\end{array}$ \\
\hline $\begin{array}{r}\text { SLO: NP [N(nomin.) }+\mathrm{N} \text { (gen.)] } \\
\text { institut izstopa } \\
\text { institut iztisnitve } \\
\text { oddelitev družbe }\end{array}$ & $\begin{array}{l}\text { EN: NP [cpd] } \\
\text { sell-out } \\
\text { squeeze-out } \\
\text { spin-off }\end{array}$ \\
\hline
\end{tabular}
ance, index structure, index constituents, etc), where the premodifying noun index is always in the singular, both if referring to a single index (SLO revizija indeksa) or several (SLO revizija indeksov). This calls for an attentive English-Slovene translator who must infer from context.

SLO: NP $[\mathrm{NP}+\mathrm{PP}]$

[prvi trgovalni dan] [brez upravičenja do dividende]

$\mathrm{EN}: \mathrm{NP}[\mathrm{N}+\mathrm{N}]$

ex-dividend date

[izvedeni finančni inštrumenti] [na blago]

commodity derivatives

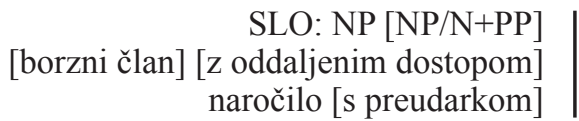

$\mathrm{EN}: \mathrm{NP}[\mathrm{Adj}+\mathrm{N}]$

remote member

discretionary order 


\section{SLO: NP [N+PP] $\quad$ EN: NP [NP+N] \\ delnice [v borzni kotaciji] [official market] shares}

\subsection{4.b. Non-transparent equivalents (continued)}

\begin{tabular}{|c|c|}
\hline $\begin{array}{r}\text { SLO: NP }[\mathrm{N}+\mathrm{PP}] \\
\text { poslovanje [s svežnji] } \\
\text { prenosi [med računi istega imetnika] } \\
\text { trgovanje [z vrednostnimi papirji] }\end{array}$ & $\begin{array}{l}\mathrm{EN} \text { : NP [N+N] } \\
\text { block trading } \\
\text { inter-accounts manage } \\
\text { securities trading } \\
\text { insider dealing }\end{array}$ \\
\hline $\begin{array}{l}\text { SLO: } \mathrm{NP}[\mathrm{N}+\mathrm{PP}] \\
\text { potrdilo o pravnomočnosti }\end{array}$ & $\begin{array}{l}\mathrm{EN}: \mathrm{NP}[\mathrm{N} \text { (gen.)+NP] } \\
\text { court's [finality seal] }\end{array}$ \\
\hline $\begin{array}{r}\text { SLO: NP [Adj+N] } \\
\text { (borzni) član } \\
\text { kosovne delnice } \\
\text { presečni datum }\end{array}$ & $\begin{array}{l}\text { EN: NP [N/NP+N] } \\
\text { member (firm) } \\
\text { [no par value] shares } \\
\text { record date }\end{array}$ \\
\hline
\end{tabular}

The above lists of corresponding construction patterns are far from exhaustive. We have merely made an attempt at classifying selected NPs both according to their structural (congruent or divergent) and lexical (transparent or oblique) properties, trying to show that there are innumerable patterns of correspondence between the two languages.

\section{Discussion and conclusion}

The present analysis has mapped out a complex web of interlingual correspondences between Slovene and English terms and expressions from the language of the stock exchange. The CA focused on the form of the identified pairs of NPs as well as on problems of meaning, discovering such interlingual difficulties as divergent polysemy, false friends, conceptual and lexical gaps. This was expected, since languages are known to differ in an unsystematic and largely unpredictable manner as to expressing the same content. We will now present our findings under the following three headings:

\section{a. Translation correspondence. Lexical (terminological) gaps}

The analysis has shown the prevalent type of translation correspondence between the identified Slovene and English NPs to be partial correspondence; it involves structural non-congruence, often coupled with complexities of meaning. Example pairs include: pooblaščenec - proxy holder, trgovalna koda — ticker, posel s svežnjem-block trade, tržna kapitalizacija - market capitalization, promet članov-turnover by member firms, nominalne delnice - par value shares, etc.

There were also instances of complete correspondence, where the English and Slovene NPs were both structurally and semantically congruent, but these were a minority. Examples include: promet — turnover, trgovalni dan — trading day. 
Examples of nil correspondence between English and Slovene NPs have revealed lexical (or, rather terminological) gaps in the languages of the stock exchange, where certain concepts exist or have been lexicalized in one language but not in the other. English terms for which there are no ready-made Slovene equivalents include insider, blue-chip, OTC, and many others. Our expectations regarding the three types of translation equivalence to be found between lexical items in two languages, as laid down in the Introduction, have thus been confirmed.

English is the lingua franca of business and finance, and this is also reflected (interlingually) in the language of the stock exchange. New concepts and terms for them are born in the Anglophone West, while the rest of the world adopts the English terminology and mostly just localizes it to a certain extent, often failing to come up with language-specific equivalent terms. As a result, Slovene stock exchange terminology abounds in carbon copies of English terms (blue-chip indeks, sistematični internalizator, insajder), directly modelled upon their English counterparts, and descriptive expressions (izvedeni finančni instrument, trgovanje na podlagi notranjih informacij, prvi trgovalni dan brez upravičenja do dividende). Especially tricky are virtually untranslatable English terms that have no lexical equivalent in Slovene at all (mistrade, market maker, OTC, hedge fund). Problematic as to their Slovene equivalents are also the idiom-like pumping dumping, painting the tape, wash sales, scalping, etc.

When there are no ready-made translation equivalents (lexical, conceptual gaps), there are at least three options - a) to make up a new Slovene term, b) to opt for a descriptive equivalent, or c) to try to find an approximate "functional" equivalent. Descriptive expressions (posli, pri katerih je sprememba lastništva finančnih instrumentov zgolj navidezna for wash sales) can be long-winded. Functional equivalents (naročilo s skrito količino is a type of order very similar to iceberg order, but not identical to iceberg) can be inaccurate. The third option, to invent a new term, lies outside the scope of translation work, since in LSP it is not customary for translators to decide on preferred terms for concepts. These are for experts to agree on (sometimes in cooperation with linguists). Once they become used and catch on, the translator may recognize them as legitimate equivalents, based on expert advice, but not before, lest they become ghost words, i.e. terms that exist on paper, but not in actual use.

There are also some Slovene terms with no mirror-image English equivalents, which is a general feature of any terminology, not just the language of the stock exchange. TUVL, BTS, and the like are limited to terms for concepts unique to the Slovene stock exchange trading platform. We can therefore speak of conceptual gaps. They are translated into English through explanatory equivalents, e.g., market maker TUVL segment.

\section{b. Interference. Collocations, false friends and the like}

It is a known fact that language learners (translators as non-native speakers of an L2 included) are inclined to draw analogies with their L1 when constructing lexical units in L2. When the two languages overlap in their formal, semantic or grammatical features, this leads to positive transfer and correct L2 lexical items (terms and expressions). Slovene terms such as mednarodni razpis, naložba, dividenda, obveznica and 
their English translations are parallel in all of the above respects and thus unproblematic in translational and contrastive terms.

If the formal, semantic or grammatical features of L1 and L2, however, do not overlap, or if they do but only partially (when meanings agree, but not forms, or the other way around), then constructing L2 terms on the analogy with L1 ones leads to lexical errors and we speak of interference or negative transfer from L1. This is a possibility with the bulk of Slovene stock exchange terms and expressions. Take aplikacija, for instance. A translator unfamiliar with the terminology of the field might be tempted to translate it as application, which, to my knowledge, has no specialized meaning in this field, the correct equivalent being the unpredictable cross trade. Or the much debated organizirani trg, which is not organized in English, but rather regulated market. Consider also the temptation of word-for-word rendering of korak kotacije, borzna kotacija, mali vlagatelj, prekinitvena avkcija and many others.

Negative transfer works in the opposite direction as well, when it is known as backward interference; under the influence of L2, learners can be often tempted to remodel their L1 lexical items to match those in L2. Even if backward interference be at work, expressions such as financial markets, legal framework, investors would not cause any problems, since they are structurally and semantically parallel to their Slovene equivalents. It gets tricky when the Slovene term for open-end fund is not odprti sklad, but rather vzajemni sklad, and especially with terms such as quote. Quote has the attractive verbal equivalent kotirati that does exist and is widely used but with a different meaning, the correct rendering being naročilo za nakup in prodajo. The cross-linguistic floors are also slippery with terms such as regulated market, which appears unproblematic at first sight; in fact, however, regulirani trg is an expression that does not exist in the Slovene language of the stock exchange, where the same concept has been lexicalized through another lexeme-organizirani trg.

Further, there are pairs of NPs that look deceptively similar, yet differ in important details, which we had anticipated in the Introduction to this article. For instance, trade in shares is trgovati $z$ delnicami, assets under management is sredstva $v$ upravljanju, right on a security is pravica iz vrednostnega papirja, bond (sg.) index is indeks obveznic (pl.), dobiček (sg.) na delnico is earnings (pl.) per share, and capital markets can either be kapitalski trg (sg.) or kapitalski trgi (pl.). Grammatical collocations are a notoriously difficult interlingual area, causing problems especially in encoding, and so are the singular-plural distinctions. When translating slovenski kapitalski trg into English, most would opt for the only reasonable choice, namely Slovene capital market. Yet the English prefer the plural expression, thus Slovene capital markets.

Due to semantic tailoring, a lexical item may be endowed with a multitude of semantic shadings and consequently receive different counterparts in the other language. $\operatorname{Trg}$, for instance, is not always market in the language of the stock exchange. Borzni and prosti trg are exchange and semi-official market, while for naročila na trgu we have orders sitting in the order book. Similarly, the adjective organizirani can either be organized (trading) or regulated (market) in English, while vzdrževalec likvidnosti can either be liquidity provider or market maker, depending on the context. 
Conversely, the EN share is not always delež in Slovene; note the pairs share - delnica, official market share — delnica na borznem trgu, market share - tržni delež, share capital-osnovni kapital. This confirms our expectations worded in the Introduction on the possible discrepancy between translation equivalents of lexemes in isolation (aplikacija-application, organiziran-organized) and those of the same lexemes in a particular context (aplikacija-cross trade, organizirani trg-regulated market). It is one of the goals of contrastive lexicology to point out such controversial pairs of collocations and thus sustain the claim that translation equivalence is largely collocation-dependent.

The analysis has also singled out Slovene and English NPs that look similar (have a similar form), but differ, at least partly, in meaning (the so-called false friends). One of them usually belongs to the LSP of the stock exchange, while the other has LGP applications divorced from the stock exchange context: quote (n.)-kotirati (v.), institutional investor - ustanovni vlagatelj, and others.

\section{c. Structural (syntactic) and semantic non-congruence}

Since LSP (of both languages) lexicalizes chiefly within the nominal domain, our analysis focused on NPs. Corresponding NPs were either structurally congruent or divergent, and lexically parallel or different, in all possible combinations, underlining a number of facts.

Equivalent NPs in English and Slovene often vary significantly as to their structure, so that despite their both belonging to the same part of speech, there are significant discrepancies as to their constituent parts. Typically, a simple NP (nezaupnica; security) may correspond to a complex NP (vote of no confidence; vrednostni papir), or two complex NPs may have different pre- or postmodification structures (whereas the SLO posel s svežnjem has the head noun postmodified by a prepositional phrase, the EN block trade is a nominal compound composed of a nominal premodifier corresponding lexically to the Slovene prepositional phrase, and a nominal head). Our expectations on the structural divergence between corresponding lexical items in the two languages, as presented in the Introduction to this article, have thus proved just.

It is difficult to establish definite patterns of structural correspondence between the terms and expressions in the two languages, i.e. we cannot claim that all English compounds of the structure $\mathrm{N}+\mathrm{N}$ (broker-dealer) are transposed into Slovene as collocations of the type Adj+N (borzni trgovec), although this might be the most recurrent type, because there are other possibilities as well: market depth-globina trga $(\mathrm{N}(\mathrm{nom})+.\mathrm{N}($ gen.) $)$, capital increase - dokapitalizacija $(\mathrm{N})$, commodity derivatives-izvedeni finančni instrumenti $(\operatorname{Adj}+\mathrm{NP}(\operatorname{Adj}+\mathrm{N}))$, etc. All we can conclude is that English and Slovene say the same things is different ways, in stock exchange terminology and, it is safe to say, elsewhere as well. Clearly this is also the result of the two languages differing with regard to morphological typology, which is evident in postmodification structures of the type stopnja donosa $(\mathrm{N}($ nom. $)+\mathrm{N}($ gen. $))$ - rate of return $(\mathrm{N}(\mathrm{nom})+.\mathrm{PP})$, where Slovene - being a synthetic language - expresses the genitive by attaching genitival suffixes to postmodifying nouns, while English - an analytic language - has the same content expressed through an independent morpheme (the preposition of). 
The two languages differ in a further respect, namely the so-called idiomacity attested by their respective terminologies. By idiomacity, we mean terms structured as compounds or single-word units, or even abbreviations, with highly specialized meanings and long track records, often lexically oblique, such as blue-chip, delisting, futures, OTC. Comparing proxy - zastopnik interesov delničarjev, profit warning - zmanjšana dobičkonosnost podjetja, quote-naročilo za nakup in prodajo, and iceberg order-naročilo s skrito količino, where Slovene uses lengthy descriptive expressions including adjectives and prepositional phrases, our point has been made. Slovene does have a few highly institutionalized terms (note for instance kupnina, dokapitalizacija, zakladne menice, VEP), but English remains the undisputed winner in this respect. As already pointed out, English is the trend-setter, as it were, in stock exchange terminology, Slovene merely trying to keep up (more or less successfully) with the pace. This idiomacity testifies to the specialized nature of English terminology as opposed to the corresponding Slovene LSP, as outlined in the Introduction.

These have been just bits and pieces of the complex web of a terminological landscape, which can only be mapped out to any degree of satisfaction for those involved through more contrastive lexicological research. Further systematic work in this area is imperative to set up a database of (problematic) corresponding stock exchange terms in Slovene and English. These are primarily needed in the form of bilingual glossaries, which are in Slovenia shockingly out of date and in which the respective Slovene industry (on behalf of their poorly equipped translators) has already shown a keen interest.

\section{References}

Ahmad, Khurshid and Steve Collingham. 1996. Terminology and Text-Based Knowledge Acquisition Projects: POINTER (Proposals for an Operational Infrastructure for Terminology in Europe). "The Importance of Terminology." URL: http:// www.computing.surrey.ac.uk/AI/pointer/report/section 1.htm.

Contrastive Analysis. Wikipedia, the Free Encyclopaedia. Accessed September 2007. URL: http://en.wikipedia.org/wiki/Contrastive_analysis.

Fisiak, Jacek. 1981. "Some introductory notes concerning contrastive linguistics" in Fisiak, J. Contrastive Linguistics and the Language Teacher. Oxford: Pergamon.

Gabrovšek, Dušan. 1996. "Contrastive Lexicology and the Wretched L1 $\rightarrow$ L2 Translator” in Klinar, S. (ed), Prispevki k tehniki prevajanja iz slovenščine v angleščino: Teorija in praksa slovensko-angleške kontrastivne analize: 13-38. Radovljica: Didakta.

Gabrovšek, Dušan. 2005. Words Galore: Aspects of General and Slovenian-English Contrastive Lexicology. Ljubljana: Filozofska fakulteta, Oddelek za anglistiko in amerikanistiko.

James, Carl. 1989. Contrastive Analysis. $8^{\text {th }}$ impression. London and New York: Longman.

Klinar, Stanko. 1996. "Samostalniškost angleščine v primeri s slovenščino (Nounoriented tendency in English)" in Klinar, S. (ed.) Prispevki k tehniki prevajanja 
iz slovenščine $\mathrm{v}$ angleščino: teorija in praksa slovensko-angleške kontrastivne analize: 149-193. Radovljica: Didakta.

Klinar, Stanko. 1995. "Čemu protistava?" in Vestnik an. 29, no. 1/2: 225-229.

Krzeszowski, Tomasz P. 1990. Contrasting Languages: The Scope of Contrastive Linguistics. Berlin, New York: Mouton de Gruyter.

Lado, Robert. 1957. Linguistics Across Cultures. Ann Arbor: University of Michigan Press.

Svensén, Bo. 1993. Practical Lexicography: Principles and Methods of DictionaryMaking. Oxford, New York: Oxford University Press.

Prispelo decembra 2007, sprejeto maja 2008

Arrived December 2007, accepted May 2008

\section{Jezik borze - Kontrastivna analiza leksike}

V članku je podana analiza jezika borze s stališča slovensko-angleške protistave. Strokovni terminologiji (samostalniške zveze, saj te tvorijo osrednji del vsakega strokovnega izrazja) smo protistavili tako v strukturnem kot v semantičnem smislu, pri čemer se je razkrila kompleksna slika medjezikovnih (ne)ujemanj.

Ugotovili smo, da se slovenski in angleški izrazi strukturno razlikujejo, in sicer na več načinov: po zgradbi se razlikujejo levi oz. desni prilastki; izrazi so sestavljeni iz enakih leksikalnih enot, ki pa se pojavijo v drugačnih vrstni redih; izrazi so sestavljeni iz povsem raznorodnih leksikalnih enot, zaradi česar so s kontrastivnega vidika povsem nepredvidljivi. Popolna prevodna ustreznost je bila pri nekaterih parih sicer res ugotovljena, a je bila najbolj pogosta le delna ustreznost. S pomočjo analize posameznih parov terminov oz. opisov smo se prepričali, da dobesedno prevajanje ni priporočljivo, saj imajo nekateri izrazi neproblematične prevodne ustreznice, kadar se pojavljajo v izolaciji, a povsem nepredvidljive in zelo specializirane ustreznice $\mathrm{v}$ borznem sobesedilu. Nadalje smo pri obeh strokovnih jezikih opazili terminološke praznine, najpogosteje na slovenski strani (ko angleščina termin za določen pojem ima, medtem ko ga slovenščina nima, zaradi česar se je v slovenskem borznem jeziku uveljavil kar - bolj ali manj poslovenjen - angleški izraz), ter lažne prijatelje (ko npr. dobesedni angleški prevod slovenskega termina sicer obstaja, a njegov pomen $\mathrm{v}$ borznem jeziku nima pomena).

V članku je podana tudi ugotovitev, da je angleščina lingua franca jezika poslovnega sveta in financ ter da ima kot taka $v$ primerjavi s slovenščino na razpolago veliko bolj idiomatično borzno izrazje, $v$ slovenščini pa se iste pojme ubesedi z daljšimi razlagalnimi in opisnimi besednimi zvezami.

\section{The Language of the Stock Exchange - A Contrastive Analysis of the Lexis}

The article analyzes the language of the stock exchange from a Slovene-English contrastive viewpoint. The two terminologies were juxtaposed as to the structural and 
semantic differences between their respective terms and expressions (we focused on nominal phrases, the chief element of any LSP), revealing a complex web of interlingual (non-)correspondences.

Slovene and English stock exchange terms and expressions have been found to diverge structurally, having either different pre- or post-modification constructions, being composed of parallel lexical elements placed in a different order, or being constructed of completely disassociated lexical elements and thus highly unpredictable from a contrastive perspective. While complete translation equivalence was identified in a few examples, partial correspondence between the analyzed nominal phrases was prevalent. The case-by-case analysis showed that word-for-word translation is not advisable despite its appeal; there are terms and expressions that have straightforward equivalents if looked at in isolation but non-transparent and highly specific counterparts in a stock exchange context. Further, the respective LSPs display terminological gaps, typically on the Slovene side (when English has a term for a concept and Slovene does not and thus mainly employs the English one, more or less naturalized), and false friends (when, for example, a direct English rendering of a Slovene term does in fact exist but has a meaning disassociated with the stock exchange world).

Finally, the article concludes that English is the lingua franca of the language of business and finance and thus operates a much more idiomatic stock exchange terminology than Slovene, which mainly employs lengthier phrases that explain and describe. 